\title{
Delayed-Onset Striatal Hands Following Basal Ganglia Anoxic Insult
}

\section{Mãos Estriatais de Início Tardio após Lesão Anóxica dos Gânglios da Base}

\author{
Sandra SOUSA $\triangle 1$, Fernando PITA 1 \\ Acta Med Port 2017 Feb;30(2):154-154 - http://dx.doi.org/10.20344/amp.7772
}

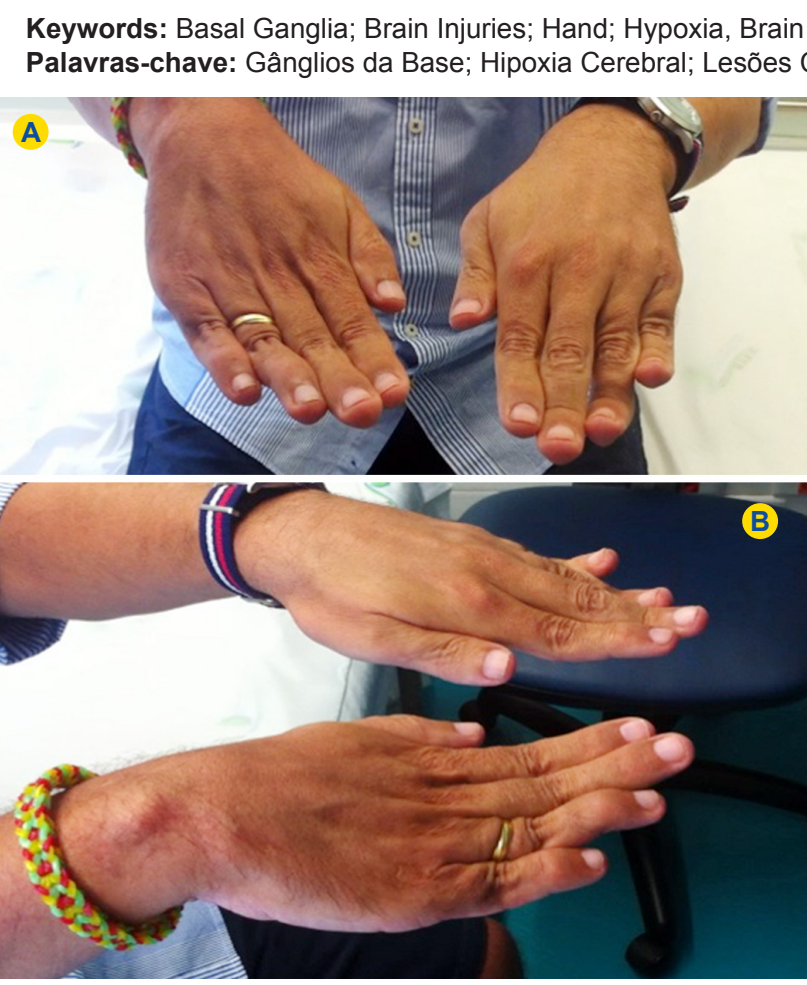

Figure 1 - Striatal hands (A, B). An abnormal painless and fixed posture present at rest and during sleep, with flexion of the metacarpophalangeal joints, extension of the proximal interphalangeal joints and flexion or extension of the distal interphalangeal joints. There is no dystonic tremor or any changes during activities or postures. Treatment with botulinum toxin and dopaminergic agents was unsuccessful.

A 56-years-old man suffered a cardiopulmonary arrest. He was reanimated but developed an anoxic-ischemic encephalopathy. Initial cranial computed tomography and brain magnetic resonance imaging (MRI) were normal. Neurological examination revealed spastic tetraparesis and dysarthria that recover after four months of rehabilitation. Six months after anoxic injury, he developed abnormal posture of the hands with difficulties on writing and buttoning. Neurological examination revealed deformity

\section{REFERENCES}

1. Ashour R, Tintner R, Jankovic J. Striatal deformities of the hand and foot in Parkinson's disease. Lancet Neurol. 2005;4:423-31.

2. Venkatesan A, Frucht S. Movement disorders after resuscitation from cardiac arrest. Neurol Clin. 2006;24:123-32.

3. Sousa S, Pita F. Mãos estriatais e alterações neuropsiquiátricas por anóxia dos gânglios da base. Sinapse. 2014;14:108-9.

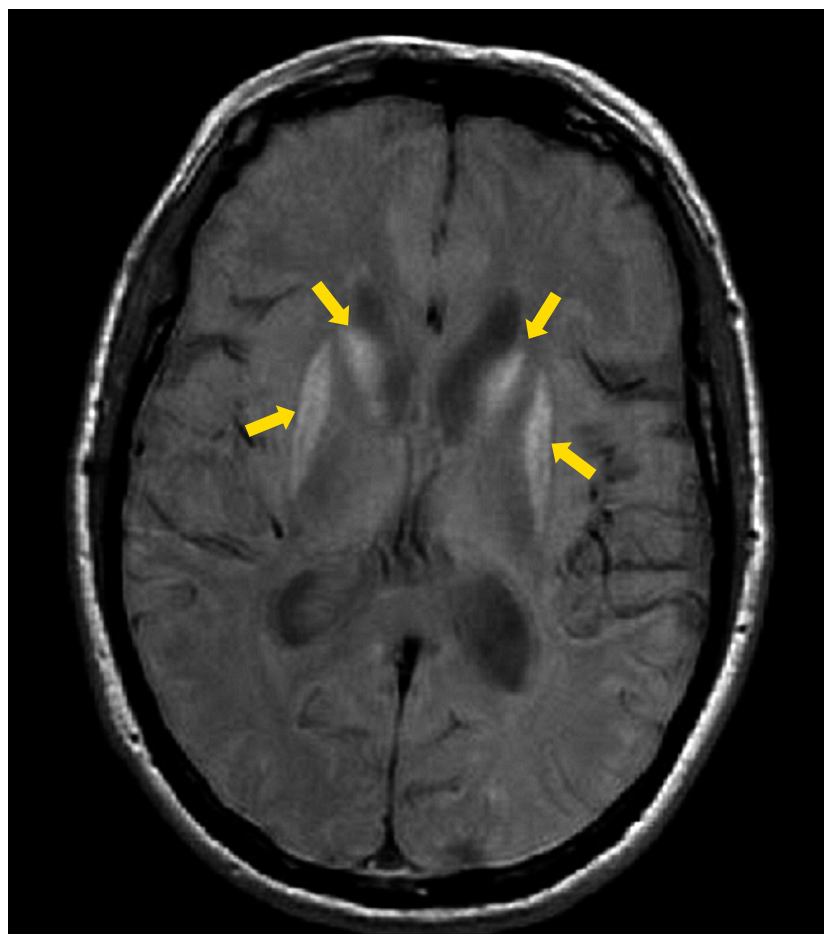

Figure 2 - T1 weighted image, showing bilateral corpus striatum and globus palidus hyperintensities after anoxic insult

of the hands consistent with striatal hands (Fig. 1), mild bilateral bradykinesia in limbs and hypomimia. There were no rigidity, tremor, pyramidal, cerebellar or sensory signs neither abnormal postures of other segments. Brain MRI was performed and showed bilateral T1 hyperintensities in basal ganglia (Fig. 2). The features of the deformity of the hands in this patient are typical of the striatal hands, a motor complication of Parkinson disease. ${ }^{1}$ Late neurological complication of anoxic-ischemic encephalopathy are known, but isolated striatal hands due to anoxic cerebral lesions are extremely rare. ${ }^{1-3}$

1. Serviço de Neurologia. Hospital de Cascais. Alcabideche. Portugal.

$\triangle$ Autor correspondente: Sandra Sousa. sandrasousa.nl@gmail.com

Recebido: 24 de abril de 2016 - Aceite: 25 de julho de 2016 | Copyright @ Ordem dos Médicos 2017 